\title{
ANALISIS SISTEM AKUNTANSI PENERIMAAN DAN PENGELUARAN KAS PADA KOPERASI PEGAWAI NEGERI SETYA GRAHA DI KECAMATAN MENDOYO TAHUN 2017
}

\author{
I Gusti Ayu Anom Pradnyawati ${ }^{1}$, I Wayan Suwendra², I Nyoman Sujana ${ }^{3}$ \\ Jurusan Pendidikan Ekonomi, Fakultas Ekonomi \\ Universitas Pendidikan Ganesha Singaraja, \\ Indonesia
}

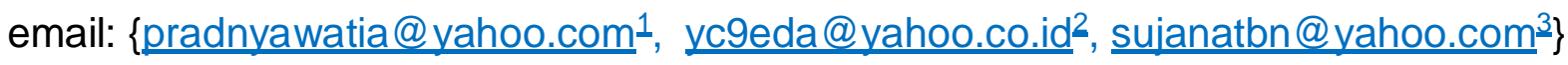

\begin{abstract}
Abstrak
Penelitian ini bertujuan untuk mengetahui sistem penerimaan kas dan pengeluaran kas. Adapun permasalahan yang dikaji dalam penelitian ini mengenai penerimaan kas dari piutang dan penerimaan kas secara tunai. Sedangkan, pengeluaran kas terdiri dari pengeluaran kas dengan memberikan kredit anggota dan untuk pembayaran biaya-biaya umum dan operasional koperasi. Penelitian ini merupakan penelitian deskriptif dengan jenis data kualitatif dan sumber data menggunakan data primer dan data sekunder. Data primer di dapat dari wawancara langsung dan data sekunder di dapat melalui buku dan bukti transaksi koperasi. Hasil penelitian ini memberikan informasi bahwa terdapat beberapa ketidaksesuaian antara prosedur dengan standar yang berlaku pada KPN Setya Graha. Masih terdapat rangkap jabatan yang terjadi, dokumen bukti penerimaan kas dan pengeluaran kas dibuat rangkap dua, dan sudah tidak melakukan pencatatan menggunakan prosedur akuntansi seperti jurnal. Namun hal ini tidak akan mengganggu berjalannya prosedur penerimaan dan pengeluaran kas. Dan dari penelitian ini diharapkan KPN Setya Graha menjalankan kegiatan sesuai dengan standar dan prosedur yang berlaku agar tidak terjadi penyalahgunaan wewenang.
\end{abstract}

Kata kunci : sistem penerimaan kas, sistem pengeluaran kas.

\begin{abstract}
This study aimed to determine the system of cash receipts and cash disbursement. The problems examined in this study were cash receipts from receivables and cash receipts in cash. Meanwhile, cash outlay consisted of cash disbursement by giving members credit and for the payment of general and operational costs of the cooperative. This study aimed is descriptive research with the type of qualitative data and data sources used primary data and secondary data. Primary data was obtained from direct interviews and secondary was obtained through books and cooperation proof of transaction. The results of this study informed that there were some discrepancies between the procedures and the standards that applied at KPN Setya Graha. There are still multiple positions, document cash receipt and cash disbursement outlays mede in duplicate, and not to use recording accounting procedure. But these discrepancies would not interfere with the cash receipts and disbursement procedures. And in this study aimed KPN Setya Graha expected running activities in accordance with the standard and procedure applicable was not so that it doesn't happen.
\end{abstract}

Keywords : cash receipt system, cash disbursement system 


\section{PENDAHULUAN}

Perkonomian Indonesia disusun berdasarkan falsafah dan ideologi Negara, yaitu Pancasila. Perekonomian yang disusun berdasarkan Pancasila terdapat dan tertulis di dalam UUD 1945 Pasal 33 yaitu Ekonomi Pancasila. Secara Ideologis normatif sumber dari dasar penjabaran Ekonomi Pancasila adalah Pancasila itu sendiri sebagaimana dinyatakan dalam Pembukaan UndangUndang Dasar 1945, dan khususnya Ayat 1 Pasal 33 UUD 1945 yang menyatakan "Perekonomian disusun sebagai usaha bersama berdasarkan azas kekeluargaan". Dan didalam penjelasannya dicantumkan bahwa badan usaha yang sesuai dengan itu adalah koperasi. Dalam hal ini koperasi ditempatkan sebagai tulang punggung perekonomian yang dianggap mampu meningkatkan ekonomi rakyat. Koperasi adalah suatu organisasi atau suatu bisnis yang didirikan oleh seseorang atau beberapa anggota untuk mencapai tujuan bersama dan untuk mencapai keuntungan bersama yang berdasarkan asas kekeluargaan. Seusai dengan UUD No 25 tahun 1992 menyatakan bahwa Koperasi adalah badan usaha yang beranggotakan orang-orang atau badan hukum Koperasi dengan melandaskan kegiatannya berdasarkan prinsip Koperasi sekaligus sebagai gerakan ekonomi rakyat yang berdasar atas asas kekeluargaan. Koperasi bertujuan untuk mensejahterakan anggotanya.

Koperasi Pegawai Republik Indonesia (KPRI), merupakan jenis koperasi yang berdasarkan status anggotanya adalah para pegawai negeri. Sebelum KPRI, koperasi ini bernama Koperasi Pegawai Negeri (KPN). $\mathrm{KPRI}$ bertujuan terutama meningkatkan kesejateraan para pegawai negeri (anggota). $\mathrm{KPRI}$ ini beranggotakan para pegawai negeri baik pegawai pusat maupun daerah. KPN Setya Graha merupakan salah satu koperasi yang bergerak dalam bidang simpan pinjam. Dimana dalam awal tahun 2017 koperasi ini terdiri dari 447 orang yang dalam perjalanannya terjadi pengurangan anggota menjadi 437 orang karena adanya pemindahan tugas, berhenti, pensiun dan meninggal. KPN Setya Graha dikelola oleh 5 orang pengurus, 3 pengawas dan 1 karyawan yang telah memiliki tugas masing-masing sesuai pembagian tugas yang telah ditetapkan dan disetujui.

Setiap perusahaan dalam menjalankan usahanya membutuhkan kas. Kas terlibat langsung dalam transaksi ataupun kegiatan operasi perusahaan. Sebagian besar transaksi perusahaan menyangkut penerimaan dan pengeluaran kas. Untuk itu diperlukan sistem akuntansi yang mengatur mengenai siklus akuntansi penerimaan dan pengeluaran kas yang dirancang sedemikian rupa sehingga setiap perubahan transaksi yang berhubungan dengan kas dapat dicatat dan terawasi dengan baik. Kas merupakan objek yang sering diselewengkan karena merupakan aktiva yang sangat liquid dari aktiva lain, dan juga karena bentuknya yang kecil, tidak diketahui pemiliknya, dapat berpindah tangankan dengan cepat serta diperlukan setiap orang. Disamping penyelewengan uang kas, sering pula timbul kerugian yang disebabkan penggunaan uang kas yang tidak efektif serta banyaknya pengeluaran yang seharusnya tidak perlu dikeluarkan tetapi dikeluarkan membuat penggunaan uang kas di perusahaan tidak berjalan dengan efektif.

Sistem akuntansi adalah organisasi formulir, catatan, dan laporan yang dikoordinasikan sedemikian rupa untuk menyediakan informasi keuangan yang dibutuhkan oleh manajemen guna memudahkan pengelolaan perusahaan. Sistem akuntansi mempunyai bagian yang sangat penting dalam suatu perusahaan. Dalam sebuah perusahaan sistem akuntansi yang sedang berjalan berfungsi untuk menghasilkan laporan kepada pihak-pihak yang berkepentingan terhadap aktivitas ekonomi dan kondisi perusahaan, mengetahui maju mundurnya suatu perusahaan dari laporan keuangan perusahaan tersebut. Pemakai informasi akuntansi biasanya dipakai secara ekstern maupun intern. Selain itu dengan adanya sistem akuntansi pada suatu perusahaan juga berfungsi sebagai dasar dalam perhitungan pajak suatu perusahaan (Mulyadi, 2010). 
Sistem Akuntansi Penerimaan Kas menurut Mulyadi (2011:456) "Sistem akuntansi penerimaan kas adalah suatu catatan yang dibuat untuk melaksanakan kegiatan penerimaan kas yang dibuat untuk melaksanakan kegiatan peeriman kas dari penjualan tunai atau dari piutang yang siap dan bebas di gunakan untuk kegiatan umum perusahaan." Menurut Mulyadi (2011:456) sumber penerimaan kas terbesar suatu perusahaan dagang berasal dari transaksi penjualan tunai. Penerimaan kas dapat dilihat dalam beberaba bagian yaitu sebagai berikut.

Penerimaan kas melalui penagih perusahaan dilaksanakan dengan prosedur berikut ini. Pertama, Bagian piutang memberikan daftar piutang yang sudah saatnya ditagih kepada Bagian Penagih. Kedua, Bagian penagih mengirimkan penagih, yang merupakan karyawan perusahaan, untuk melakukan penagihan kepada debitur. Ketiga, Bagian penagihan menerima cek/uang atas nama dan surat pemberitahuan dari debitur. Keempat, Bagian penagihan menyerahkan cek/uang kepada bagian kasa. Kelima, Bagian penagihan memberikan surat pemberitahuan kepada bagian piutang untuk kepentingan posting ke dalam kartu piutang. Keenam, Bagian kasa mengirimkan kuitansi sebagai tanda penerimaan kas kepada debitur. Ketujuh, Bagian kasa menyetorkan cek/uang ke bank. Apabila menggunakan cek, setelah cek dilakukan endorsement oleh pejabat yang berwenang. Kedelapan, Bank perusahaan melakukan clearing atas cek tersebut ke bank debitur.

Sistem Penerimaan Kas dari Piutang melalui Pos dilaksanakan dengan prosedur sebagai berikut. Pertama, Bagian Penagihan mengirim faktur penjualan kredit kepada debitur pada saat transaksi penjualan kredit terjadi. Kedua, Debitur mengirim cek atas nama yang dilapisi surat pemberitahuan melalui pos. Ketiga, Bagian Sekretariat menerima cek atas nama dan surat pemberitahuan (remittance advice) dari debitur. Keempat, Bagian Sekretariat menyerahkan cek kepada Bagian kasa. Kelima, Bagian Sekretariat menyerahkan surat pemberitahuan kepada Bagian Piutang untuk kepentingan posting ke dalam kartu piutang. Keenam, Bagian Kasa mengirim kuitansi kepada debitur sebagai tanda terima pembayaran dari debitur. Ketujuh, Bagian kasa menyetorkan cek ke bank, setelah cek atas cek tersebut dilakukan endorsement oleh pejabat yang berwenang. Kedelapan, Bank perusahaan melakukan clearing atas cek tersebut ke bank debitur.

Sistem penerimaan kas dari piutang melalui Lock-Box-Collection Plan dilaksanakan dengan prosedur sebagai berikut. Pertama, Bagian Penagihan mengirim faktur penjualan kredit kepada debitur pada saat transaksi penjualan kredit terjadi. Kedua, Debitur melakukan pembayaran utangnya pada saat faktur jatuh tempo dengan mengirimkan cek dan surat pemberitahuan ke $P O B o x$ di kota terdekat. Ketiga, Bank membuka $P O$ Box dan mengumpulkan cek dan surat pemberitahuan yang diterima oleh perusahaan. Keempat, Bank membuat daftar surat pemberitahuan. Dokumen ini dilampiri dengan surat pemberitahuan dikirimkan oleh bank ke Bagian sekretariat. Kelima, Bank mengurus check clearing. Keenam, Bagian Sekretariat menyerahkan surat pemberitahuan kepada Bagian Piutang untuk mengkredit rekening pembantu piutang debitur yang bersangkutan. Ketujuh, Bagian Sekretariat menyerahkan daftar surat pemberitahuan ke Bagian Kasa. Kedelapan, Bagian Kasa menyerahkan daftar surat pemberitahuan ke Bagian Jurnal untuk dicatat di dalam jurnal penerimaan kas.

Selanjutnya, Sistem Akuntansi Pegeluaran Kas menurut Muyadi (2011:509), "Sistem akuntansi pengeluaran kas pada umumnya didefinisikan sebagai organisasi formulir, catatan dan laporan yang dibuat untuk melaksanakan kegiatan pengeluaran baik dengan cek maupun dengan uang tunai untuk mempermudah setiap pembiayaan pengelolaan perusahaan.

Pengeluaran kas dalam perusahaan dilakukan dengan menggunakan cek. Pengeluaran kas yang tidak dapat dilakukan dengan cek (biasanya karena jumlahnya relative kecil), dilaksanakan melalui dana kas kecil yang diselenggarakan dengan salah satu 
di antara dua sistem yaitu fluctuating fund balance system dan imprest system. (Mulyadi: 510). Dokumen yang digunakan adalah Bukti Kas Keluar, Cek, Permintaan Cek (Check Request). Catatan Akuntansi yang Digunakan adalah Jurnal Pengeluaran Kas (Cash Disbursement Journal), Register Cek (Check Register). Fungsi yang Terkait adalah Fungsi yang memerlukan pengeluaran kas, Fungsi kas, Fungsi akuntansi, Fungsi pemeriksa intern. Unsur Pengendalian Intern adalah Fungsi penyimpanan kas kecil harus terpisah dari fungsi akuntansi,dan Transaksi penerimaan dan pengeluaran kas tidak boleh dilaksanakan sendiri oleh bagian kasa sejak awal sampai akhir, tanpa campur tangan dari fungsi yang lain.

Prosedur pembentukan dana kas kecil dengan imprest system tidak berbeda dengan prosedur pembentukan dana kas kecil dengan fluctuating-fund-balance system. Adapun prosedur pembentukan dana kas kecil yaitu sebagai berikut. Pertama, Bagian utang mencatat pembentukan dana kas kecil didalam register bukti kas keluar. Kedua, Bukti kas keluar dilampiri dengan surat keputusan pembentukan dana kas kecil diserahkan oleh bagian utang ke bagian kasa. Ketiga, Berdasarkan bukti kas keluar tersebut, bagian kasa membuat cek atas nama dan memintakan tanda tangan otorisasi atas cek. Keempat, Cek diserahkan kepada pemegang dana kas kecil dan bukti kas keluar diserahkan kepada bagian jurnal setelah dibubuhi cap lunas oleh bagian kasa. Kelima, Bagian jurnal mencatat pengeluaran kas dalam register cek.

Kemudian, Laporan arus kas melaporkan arus kas selama periode tertentu dan diklasifikasikan menurut aktivitas operasi, investasi, dan pendanaan. Entitas melaporkan arus kas dari aktivitas operasi dengan menggunakan salah satu dari metode sebagai berikut. Pertama, Metode Langsung, dengan metode ini kelompok utama dari penerimaan kas bruto dan pembayaran kas bruto diungkapkan. Kedua, Metode Tidak Langsung, dengan metode ini laba atau rugi disesuaikan dengan mengoreksi pengaruh transaksi yang bersifat nonkas, penangguhan, atau akrual dari penerimaan atau pembayaran kas untuk operasi di masa lalu atau masa depan, dan pos penghasilan atau beban yang berhubungan dengan arus kas investasi atau pendanaan.

KPN Setya Graha merupakan salah satu koperasi Simpan-pinjam yang dimana anggotanya merupakan semua pegawai negeri yang ada di Kecamatan Mendoyo. Sistem akuntansi penerimaan dan pengeluaran kas menjadi sangat diperhatikan karena kas merupakan kekayaan sebuah perusahaan yang sangat liquid. Sistem penerimaan dan pengeluaran kas dalam KPN Setya Graha telah dilaksanakan dengan baik, di mana saat waktu pembayaran piutang atau pembayaran simpanan (pokok, wajib dan sukarela) akan diambil/diterima oleh karyawan apabila transaksi penerimaan kas itu terjadi di luar koperasi. Sedangkan jika terjadi didalam koperasi akan ditangani langsung oleh bendahara. Setiap terjadi penerimaan dan pengeluaran kas akan dibuatkan nota atau bukti sebanyak 1 set (2 rangkap) dimana 1 rangkap disimpan oleh anggota dan 1 rangkap disimpan di koperasi. Dalam KPN Setya Graha kas yang ada jarang mengendap atau disimpan di Bank, karena uang tersebuat akan langsung berputar apabila masih ada sisa baru akan di simpan di dalam Bank dan setiap terjadi transaksi baik penerimaan maupun pengeluaran kas akan diberikan pengesahan oleh pengurus yang berwenang. Setiap terjadi pengeluaran kas seperti peminjaman uang yang dilakukan anggota akan memerlukan form peminjaman yang terdiri dari KTP, KK, NPWP, dan Nomor Rekening Bank. Setelah disetujui adanya pinjaman pengurus yang berwenang di dalam pengadaan pengeluaran kas akan menyiapkan dokumen, catatan dan kas yang diperlukan. Setiap akhir periode baru diadakan pencatatan dan pembuatan pembukuan secara lengkap. Maka dari hasil observasi awal yang penulis temukan di atas, penulis ingin untuk mencari sistem penerimaan dan pengeluaran kas dalam KPN Setya Graha secara lengkap dan terperinci serta membandingkan membandingkan sistem yang dipakai di KPN Setya Graha dengan Standar Akuntansi yang ada. 
Dalam KPN Setya Graha sistem penerimaan dan pengeluaran kas sudah berjalan sesuai dengan prosedur yang telah ditetapkan, namun kadang-kadang sering terjadi kesalahan baik dari pengurus maupun dari anggotanya sendiri. Berdasarkan latar belakang, rumusan masalah dan tujuan di atas maka penulis ingin melakukan pembahasan melalui tugas akhir ini dengan meneliti Analisis Sistem Akuntansi Penerimaan dan Pengeluaran Kas Pada Koperasi Pegawai Negeri Setya Graha Di Kecamatan Mendoyo Tahun 2017.

\section{METODE}

Jenis penelitian ini adalah penelitian deskriptif. Menurut Punaji Setyosari (2010) "penelitian deskriptif adalah penelitian yang bertujuan untuk menjelaskan atau mendeskripsikan suatu keadaan, peristiwa, objek apakah orang, atau segala sesuatu yang terkait dengan variabel-variabel yang bisa dijelaskan baik dengan angka-angka maupun kata-kata". Penelitian deskriptif dilakukan untuk memperoleh informasi mengenai sistem penerimaan dan pengeluaran kas yang sesuai dengan standar akuntansi yang berlaku.

Penelitian ini dilaksanakan di Koperasi Pegawai Negeri Setya Graha di Desa Penyaringan, Kecamatan Mendoyo, Kabupaten Jembrana, Bali.

Subjek yang dimaksud dalam penelitian ini adalah KPN Setya Graha. Sedangkan objek dari penelitian ini adalah sistem penerimaan dan pengeluaran kas pada KPN Setya Graha.

Jenis data dalam penelitian ini adalah data kualitatif berupa data yang dinyatakan dengan kata-kata mengenai sistem penerimaan dan pengeluaran kas berupa bukti transaksi (Bukti Penerimaan Kas, Bukti Pengeluaran Kas, dan Struktur Organisasi), Flowchart Penerimaan kas dan Flowchart Pengeluaran kas.

Adapun sumber data yang dipergunakan dalam penelitian ini adalah data primer dan data sekunder. Data primer dalam penelitian ini berupa hasil wawancara. Dalam penyusunan tugas akhir ini penulis memperoleh data langsung pada bagian keuangan, berupa penjelasan dan penjabaran yang diungkapkan mengenai data penelitian. Data sekunder diperoleh dari buku dan bukti transaksi yang ada dalam Koperasi.

Dalam penelitian ini wawancara dilakukan untuk mendapatkan data tentang sistem penerimaan kas dan pengeluaran kas dari pengurus dan karyawan yang ada dalam KPN Setya Graha.

Dalam penelitian ini dokumentasi digunakan untuk mendapatkan data-data yang berhubungan dengan penelitian ini seperti pembagian tugas pengurus dan pegawai, visi dan misi koperasi, serta data lain yang diperlukan dalam penelitian ini.

Metode Observasi menurut Sugiyono (2009:144) adalah sebagai berikut: "Teknik pengumpulan data mempunyai ciri yang spesifik bila dibandingkan dengan teknik yang lain. Observasi tidak terbatas pada orang, tetapi juga objek-objek alam yang lain."

Instrumen penelitian adalah alat-alat yang digunkan untuk mengumpulkan data, instrumen penelitian ini dapat berupa kuisioner, formulir observasi, formulir-formulir lain yang berkaitan dengan pencatatan data dan sebagainya. Pedoman Wawancara peneliti menggunakan pedoman wawancara berupa daftar pertanyaan yang memuat tentang pokok-pokok informasi yang akan digali berupa matrik wawancara. Dalam hal ini pedoman wawancara yang dipergunakan dalam sistem penerimaan dan pengeluaran kas dilihat dari segi pencatatan, penyusunan, pelaporan dan penyajian laporan keuangan

Daftar Cocok (Checklist) daftar cocok mempunyai bentuk yang lebih sederhana karena dengan daftar cocok peneliti bermaksud meringkas penyajian pertanyaan, serta mempermudah responden dalam memberikan responnya. Daftar cocok dalam penelitian ini digunakan untuk mengumpulkan data dokumen yang digunakan untuk mencatat sistem yang dijalankan.

Teknik analisis data yang digunakan dalam penelitian ini adalah teknik analisis deskriptif dengan pendekatan kualitatif. Analisis kualitatif dilakukan pada sistem penerimaan dan pengeluaran kas. Dalam penelitian ini metode analisis data yang digunakan adalah model analisis menurut 
Miles dan Huberman. Adapun teknik dalam analisis dana ini adalah sebagai berikut. Data Reduction (Reduksi Data) Reduksi data berarti merangkum, memilih hal pokok, memfokuskan pada hal yang penting, dicari pola dan temanya. Dalam hal ini peneliti akan memfokuskan pada arus sistem penerimaan dan pengeluaran kas.

Data Display (Penyajian Data) Data display berarti mendisplay data yaitu menyajikan data dalam bentuk uraian singkat, bagan, hubungan antar kategori, dan sebagainya. Menyajikan data yang sering digunakan dalam penelitian kualitatif adalah bersifat naratif. Ini dimaksud untuk memahami apa yang terjadi, merancanakan kerja selanjutnya berdasarkan apa yang dipahami.

Membandingkan Data dengan PSAK Dalam penelitian ini membandingkan data yang setelah data tersebut dibuat dalam bentuk yang lebih singkat dan sesuai dengan kategori yang diperlukan dengan PSAK yang berlaku dalam sistem penerimaan dan pengeluaran kas. Dalam membandingkan data tentang sistem penerimaan dan pengeluaran kas dengan PSAK ini di lihat dari segi pencatatan, penyusunan laporan, pelaporan dan penyajian laporan keuangan.

Conclusing Drawing/Verification Langkah terakhir dari model ini adalah penarikan kesimpulan dan verifikasi. Kesimpulan dalam penelitian mungkin dapatb menjawab rumusan masalah yang dirumuskan sejak awal namun juga tidak, karena masalah dan rumusan masalah dalam penelitian kualitatif bersifat sementara dan berkembang setelah peneliti ada di lapangan. Kesimpulan penelitian kualitatif merupakan temuan baru yang sebelumnya belum ada yang berupa deskripsi atau gambaran yang sebelumnya belum jelas menjadi jelas dapat berupa hubungan kausal/ interaktif dan hipotesis/ teori.

Sistem penerimaan kas dari piutang melalui penagih koperasi adalah sebagai berikut. Pertama, Bagian piutang memberikan daftar piutang yang sudah saatnya ditagih kepada Bagian Penagih. Kedua, Bagian penagih mengirimkan tagihan, yang merupakan karyawan koperasi, untuk melakukan penagihan kepada anggota. Ketiga,
Bagian penagihan menerima uang atas nama dan surat pemberitahuan dari anggota. Keempat, Bagian penagihan menyerahkan uang kepada bagian kasa. Kelima, Bagian penagihan memberikan surat pemberitahuan kepada bagian piutang untuk kepentingan posting ke dalam kartu piutang. Keenam, Bagian kasa mengirimkan kuitansi sebagai tanda penerimaan kas kepada anggota. Bagian kasa menyetorkan uang ke bank.

Sistem penerimaan kas dari pembayaran simpanan koperasi adalah sebagai berikut. Pertama, Bagian administrasi Menerima uang angsuran simpanan dan buku angsuran yang diserahkan oleh nasabah untuk pembayaran angsuran. Kedua, Membuatkan slip setoran angsuran rangkap dua. 1 untuk anggota dan 2 untuk diarsipkan. Ketiga, Meminta anggota untuk menandatangani slip setoran angsuran. Keempat, Mencatat angsuran di buku angsuran. Kelima, Menyerahkan slip setoran dan buku angsuran simpanan kepada anggota. Keenam, Mencatat dibuku harian kasir. Ketujuh, Slip setoran angsuran simpanan di arsipkan. Kedelapan, Bagian dana tabungan/simpanan kemudian mencatat dengan menggunakan komputer.

Sistem penerimaan kas dari angsuran pinjaman/kredit koperasi adalah sebagai berikut. Pertama, Kasir menerima uang angsuran pinjaman dari anggota dan menyiapkan bukti kas masuk rangkap 4 . Kedua, Kasir menandatangani bukti kas masuk dan membubuhkan cap LUNAS serta menyerahkan bukti kas masuk lembar 2 ke peminjam. Ketiga, Kasir menyimpan bukti kas masuk lembar 4 dan membukukan ke buku harian kas. Keempat, Kasir menyerahkan bukti kas masuk lembar 3 ke bagian pinjaman dan bukti kas masuk lembar 1 ke bagian akuntansi. Kelima, Bagian pinjaman mengarsipkan bukti kas masuk lembar 3 yang diterima dari kasir dan mencatat ke kartu pinjaman. Keenam, Bagian akuntansi mengarsipkan bukti kas masuk lembar 1 yang diterima dari kasir dan mencatat ke dalam jurnal kas masuk dan kartu pinjaman.

Sistem penerimaan kas dari pelunasan angsuran koperasi adalah sebagai berikut. Pertama, Bagian Administrasi keuangan/kasir 
menerima uang dan buku angsuran dari anggota yang akan melunasi hutang. Menyerahkan uang dan buku angsuran kepada bagian dana simpanan/tabungan dan meminta sisa pinjaman. Membuat slip rangkap dua. Mencatat di buku mutasi harian. Memberi tanda lunas. Simpan buku angsuran. Menyerahkan slip pelunasan kepada nasabah. Mengarsipkan slip pelunasan. Kedua, Bagian Dana Simpanan/Tabungan memeriksa buku angsuran dan uang dari kasir. Menyerahkan buku angsuran kepada manajer dan meminta persetujuan. Menyerahkan buku angsuran ke bagian administrasi keuangan/kasir dan jumlah yang harus dilunasi. Mencatat pelunasan ke komputer. Ketiga, Manajer menyetujui dan memberi paraf. Menyerahkan buku ke bagian dana simpanan/tabungan.

Sistem penerimaan kas dari bank berupa bunga simpanan adalah sebagai berikut. Pertama, Bukti kas masuk dibuat dalam rangkap 3 oleh bagian administrasi. Kedua, Bukti yang pertama diserahkan untuk bagian administrasi/bendahara. Ketiga, Bukti yang kedua untuk bagian akuntansi (pembukuan). Keempat, Dan lembar ketiga digunakan untuk arsip koperasi.

Sistem pengeluaran kas dapat dilihat dari berbagai segi yaitu sistem pengeluaran kas. Adapun langkah-langkah sistem pengeluaran kas dari penggajian anggota koperasi adalah sebagai berikut. Pertama, Berdasarkan dokumen bukti kas keluar lembar pertama, dicatat oleh bagian utang kewajiban gaji ke dalam register bukti kas keluar. Dalam jurnal tersebut digunakan rekening gaji dan upah sebagai clearing account. Kedua, Berdasarkan bukti memorial, bagian jurnal mencatat distribusi biaya gaji ke dalam jurnal umum. Ketiga, Berdasarkan dokumen bukti kas keluar yang telah di cap lunas oleh fungsi keuagan, bagian jurnal mencatat pembayaran gaji ke dalam register bukti kas keluar. Keempat, Berdasarkan bukti memorial yang dilampiri dengan rekap daftar gaji. Kartu biaya mecatat biaya tenaga kerja ke dalam buku pembantu (kartu biaya).

Sistem pengeluaran kas dari pemberian kredit koperasi adalah sebagai berikut. Pertama, Anggota harus mengajukan persyaratan yang berupa Fotocopy KTP suami istri, Fotocopy KK (Kartu Keluarga), Fotocopy barang jaminan, Slip pencairan dana, dan Surat permohonan. Kedua, Bagian Pinjaman/Pembiayaaan memeriksa kelengkapan berkas permohonan berupa fotocopy KTP suami istri, KK dan barang jaminan. Menyerahkan berkas permohonan kepada ketua Koperasi. Ketiga, Kemudian ketua koperasi Menerima berkas permohonan. Menganalisa permohonan. Melakukan wawancara. Jika setuju, serahkan berkas permohonan ke bagian pinjaman dan pembiayaan. Keempat, Bagian peminjaman membuat akad perjanjian pembiayaan dengan anggota. Kemudian menyerahkan ke kasir. Kelima, Kemudian bagian administrasi keuangan/bendahara membuat slip pencairan dana. Menyiapkan buku angsuran. Melakukan pembayaran ke nasabah. Dan membuat arsip slip pencairan dana.

Sistem pengeluaran kas dari penarikan simpanan koperasi adalah sebagai berikut. Pertama, Bagian administrasi keuangan/kasir membuat slip penarikan simpanan yang terdiri dari 2 rangkap. Kedua, Meminta tanda tangan anggota pada slip penarikan simpanan. Ketiga, Mencatat penarikan simpanan pada buku simpanan. Keempat, Menyerahkan slip penarikan simpanan pada nasabah. Kelima, Mencatat transaksi pada buku mutasi harian kasir. Keenam, Mengambil uang yang ada di bank untuk di setorkan kepada anggota. Ketujuh, Menyimpan arsip slip penarikan simpanan. Kedelapan, Bagian dana simpanan/tabungan mencatat dengan komputer.

Sistem pengeluaran kas dari pembayaran biaya-biaya umum dan operasional koperasi adalah sebagai berikut. Pertama, Kasir menerima permintaan kas secara lisan dari pemakai kas. Kedua, Kemudian membuat pengeluaran kas sebanyak 2 rangkap. Ketiga, Lalu dilakukan otorisasi oleh pejabat yang berwenang/ketua koperasi beserta uang yang telah disetujui oleh ketua koperasi. Keempat, Bukti pengeluaran kas rangkap ke-2 diserahkan kepada pemakai kas beserta penyerahan uang. Kelima, Bukti pengeluaran rangkap ke-1 diserahkan ke 
bagian pembukuan/bagian akuntansi untuk diperiksa dan dilakukan penjurnalan pengeluaran kas.

\section{HASIL DAN PEMBAHASAN Hasil}

Sistem penerimaan kas dari penagih koperasi adalah sebagai berikut. Pertama, Bagian piutang memberikan daftar piutang yang sudah saatnya ditagih kepada bagian penagih. Kedua, Bagian penagih melakukan penagihan kepada anggota koperasi pada instansi masing-masing, apabila terjadi keterlambatan pembayaran yang dilakukan anggota oleh bendahara masing-masing instansi terkait. Ketiga, Bagian penagih menerima uang dan surat order dari anggota. Keempat, Bagian penagih kemudian menyerahkan uang kepada bendahara. Jika pada saat penyerahan uang yang dilakukan oleh bagian penagih tidak terdapat bendahara yang bertugas, maka tugas bendahara ini digantikan oleh ketua koperasi. Kelima, Bendahara/ketua membuat bukti kas masuk rangkap 2. 1 untuk anggota dan 2 untuk arsip koperasi itu sendiri. Keenam, Bendahara dan juru buku melakukan pemostingan pada buku piutang. Ketujuh, Bagian penagih mengirimkan bukti kas masuk rangkap pertama kepada anggota. Kedelapan, Bendahara tidak langsung menyimpan uang yang diterima ke bank karena uang yang ada dalam KPN Setya Graha akan terus berputar. Apabila masih ada sisa baru akan disimpan di dalam bank.

$\begin{array}{llr}\text { Sistem } & \text { penerimaan kas dari } \\ \text { pembayaran } & \text { simpanan, } & \text { angsuran } \\ \text { pinjaman/kredit } & \text { koperasi, dan pelunasan }\end{array}$ angsuran adalah sebagai berikut. Pertama, Bendahara menerima uang dan buku angsuran yang diserahkan oleh anggota. Kedua, Bendahara membuat slip bukti kas masuk rangkap 2. 1 untuk anggota dan 2 untuk arsip koperasi. Ketiga, Meminta tanda tangan anggota pada slip bukti kas masuk yang dibuat. Keempat, Mencatat pada buku angsuran anggota. Kelima, Menyerahkan slip setoran/bukti kas masuk dan buku angsuran kepada anggota. Keenam, Bendahara mencatat pada buku harian kas dan langsung memposting pada rekening anggota yang membayar. Ketujuh, Bendahara mengarsipkan slip bukti kas masuk. Kedelapan, Bendahara langsung mencatat simpanan anggota tersebut dalam komputer.

Sistem penerimaan kas dari bunga bank adalah sebagai berikut. Pertama, Bendahara mengambil uang ke bank. Kedua, Bukti kas masuk dibuat rangkap 2 oleh bendahara. Ketiga, Lembar pertama di arsipkan oleh bendahara. Keempat, Lembar kedua dibuatkan pembukuan.

Sistem pengeluaran kas pada koperasi yaitu sebagai berikut. Sistem pengeluaran kas dari pemberian kredit koperasi adalah sebagai berikut Anggota mengajukan surat permohonan peminjaman uang yang berisikan fotocopy KTP suami-istri, fotocopy kartu keluarga. Ketua memeriksa kelengkapan berkas yang diajukan, melakukan wawancara dengan anggota dan ketua bertugas menerima dan menolak kredit yang diajukan. Sekretaris, karyawan dan ketua membuat surat perjanjian. Bendahara mengambil uang yang diperlukan. Bendahara membuat slip bukti kas keluar rangkap 2. Menyiapkan buku angsuran dan melakukan pembayaran sejumlah uang yang dipinjam anggota. Bukti kas keluar lembar pertama diserahkan kepada anggota dan rangkap ke 2 diarsipkan oleh bendahara.

Sistem pengeluaran kas dari penggajian pengurus koperasi Juru pembukuan membuat kwitansi rangkap 2 . Bendahara mengeluarkan uang sejumlah yang diperlukan dan mencatat pada kwitansi bukti kas keluar. Bendahara memberikan cap LUNAS pada kwitansi bukti kas keluar. Bukti pertama diberikan kepada pengurus dan pengawas yang menerima gaji. Bukti kedua diarsipkan oleh bendahara.

Sistem pengeluaran kas untuk biaya umum dan operasional koperasi adalah sebagai berikut Bendahara membuat slip bukti kas keluar rangkap 2. Ketua menyetujui pembayaran biaya-biaya yang diperlukan beserta uang yang telah disetujui. Bendahara mengambil uang yang diperlukan beserta slip bukti kas keluar rangkap pertama. Bukti kas rangkap 2 diserahkan kepada bagian pembukuan dan langsung diarsipkan oleh bagian pembukuan. 


\section{Pembahasan}

Sistem Penerimaan kas

Pada KPN Setya Graha pengurus yang bertugas untuk mejalankan sistem penerimaan kas adalah Ketua, Bendahara dan Karyawan. Setiap terjadi transaksi ketua bertugas untuk menyetujui dan membantu melaksanakan penerimaan kas, bendahara bertugas untuk menerima uang, membantu dalam pembukuan dan pengarsipan dokumen yang digunakan, dan karyawan bertugas untuk membuat pembukuan setiap terjadi transaksi penerimaan kas pada KPN Setya Graha.

Hasil penelitian yang ini mendukung teori Mulyadi (2001) tentang sistem penerimaan dan pengeluaran kas di mana sistem penerimaan kas terdiri dari penerimaan kas secara tunai dan penerimaan kas secara kredit sedangkan sistem pengeluaran kas terdiri dari sistem pengeluaran kas secara tunai maupun dengan cek. Dalam KPN Setya Graha tidak terdapat pengeluaran kas menggunakan cek. Penelitian ini juga sejalan dengan penelitian lain yang dilakukan oleh Muhammad Irfai (2009) yang meneliti tentang sistem penerimaan kas pada Koperasi Syirkah Muawanah Bondho Tumoto, dan penelitian dari Atik Styowati, dkk. tentang sistem pengeluaran kas pada KUD Karya Mina Tegal.

Dalam KPN Setya Graha memiliki prinsip keterbukaan di mana apabila salah satu pengurus tidak dapat melaksanakan tugas dalam penerimaan kas koperasi maka akan digantikan atau dibantu oleh pengurus lainnya yang ada pada saat penerimaan kas tersebut terjadi. Penerimaan kas pada koperasi uang yang diterima tidak akan langsung disimpan tetapi uang yang diterima itu akan langsung diputarkan dan apabila masih ada sisa baru uang tersebut akan disimpan pada bank. Koperasi ini sudah menggunakan sistem rekening pribadi masing-masing anggota dan apabila ada penerimaan kas dari anggota akan langsung masuk ke rekening pribadi dari anggota yang membayar. Pencatatan dengan menggunakan komputer juga telah dilaksanakan oleh KPN Setya Graha. Namun, pada KPN Setya Graha sudah tidak lagi menggunakan jurnal dalam pencatatan penerimaan kas karena akan langsung masuk ke rekening anggota. Setiap bulan akan diadakan pemeriksaan buku angsuran yang dilaksanakan oleh ketua koperasi sendiri dan setiap 3 bulan sekali dilakukan pemeriksaan oleh pengawas koperasi bersama dengan tim pengawas lainnya.

Penerimaan kas pada KPN Setya Graha ada beberapa yang dilaporkan pada laporan arus kas sesuai dengan PSAK yaitu yang pertama dari aktivitas operasi antara lain penagihan piutang dari pelanggan, penerimaan bunga dan deviden dari investasi, dan penerimaan kegiatan operasi lainnya. Kedua yaitu dari aktivitas investasi antara lain penerimaan kas atas pinjaman yang diberikan. Ketiga yaitu dari aktivitas pendanaan antara lain peminjaman uang.

Pada KPN Setya terdapat beberapa ketidaksesuaian antara prosedur yang dijalankan dengan standar yang berlaku. Masih terdapat penumpukan tugas yang dijalankan oleh pengurus dan setiap terjadi transaksi sudah tidak lagi memakai jurnal yang seharusnya digunakan untuk mencatat apabila terjadi transaksi pada penerimaan kas.

\section{Sistem Pengeluaran Kas}

Sistem pengeluaran kas pada KPN Setya Graha dijalankan oleh 3 pengurus diantaranya ketua bertugas untuk menyetujui adanya kredit dan pengeluaran kas untuk kegiatan koperasi, bendahara yang bertugas untuk menyiapkan uang dan karyawan yang membatu menyiapkan buku angsuran dan membantu bendahara dalam mencatat setiap terjadi transaksi. Setiap terjadi pengeluaran kas tidak menggunakan jurnal karena setiap kwitansi pengeluaran kas langsung dicatat pada kwitansi/nota yang digunakan. Setiap ada anggota yang akan meminjam uang pada koperasi ketua berhak untuk menerima atau menolak pengajuan kredit yang diserahkan oleh anggota.

Pengeluaran kas pada KPN Setya Graha ada beberapa yang dilaporkan pada laporan arus kas sesuai dengan PSAK yaitu yang pertama dari aktivitas operasi antara lain, pembayaran untuk karyawan, pembayaran bunga dan pajak penghasilan, dan 
pembayaran kegiatan operasi lainnya. Kedua yaitu dari aktivitas investasi antara lain pemberian pinjaman. Ketiga yaitu dari aktivitas pendanaan antara lain pembayaran deviden, pembayaran pokok pinjaman hutang.

Sistem pengeluaran kas pada KPN Setya Graha lebih banyak dilakukan oleh bendahara dan ketua di mana bendahara mengambil tugas untuk mencatat langsung terjadinya transaksi dan menyimpan/mengarsipkan kwitansi yang dipergunakan dalam penerimaan kas.

\section{SIMPULAN DAN SARAN \\ Simpulan}

Sistem penerimaan kas dan pengeluaran kas pada KPN Setya Graha dikerjakan oleh bendahara sehingga terjadi rangkap jabatan.

Dokumen yamg digunakan baik bukti penerimaan kas maupun pengeluaran kas dibuat rangkap dua. Dengan ketentuan rangkap pertama untuk nasabah (anggota) dan rangkap kedua digunakan untuk arsip koperasi.

Sistem penerimaan dan pengeluaran kas tidak menggunakan prosedur akuntansi.

\section{Saran}

Graha.

Bagi Koperasi Pegawai Negeri Setya

Hasil penelitian ini diharapkan koperasi lebih dapat menjalankan kegiatannya sesuai dengan prosedur yang berlaku agar tidak terjadi rangkap jabatan yang dilakukan bendahara sehingga bisa menimbulkan penyalahgunaan wewenang.

Hasil penelitian ini diaharapkan koperasi untuk membuat dokumen bukti penerimaan kas seharusnya dibuat rangkap 3 yang pembagiannya rangkap pertama untuk nasabah (anggota), rangkap kedua untuk bagian pembukuan dan rangkap ketiga untuk arsip koperasi. Bukti pengeluaran kas dibuat rangkap 2 yang pembagiannya rangkap pertama untuk nasabah (anggota) dan rangkap kedua untuk arsip koperasi.

Hasil penelitian ini diharapkan koperasi dapat menggunakan prosedur akuntansi sesuai dengan PSAK no 2 revisi 2009.
Hasil penelitian ini diharapkan dapat dijadikan dasar untuk penelitian selanjutnya dengan menggunakan sistem-sistem lainnya.

\section{DAFTAR PUSTAKA}

Amin Widjaja, Tunggal. 2002. Akuntansi Untuk Koperasi. Jakarta: PT Rineka Cipta.

Arikunto, Suharsimi. 2010. Prosedur Penelitian: Suatu Pendekatan Praktik. Jakarta: Rineka Cipta.

Dantes, Nyoman. 2012. Metode Penelitian. Yogyakarta: Andi

Fahmi, Muhammad dkk. 2015. Analisa Sistem Akuntansi Penerimaan Dan

Pengeluaran Kas Guna Mendukung Pengendalian Intern Perusahaan (Studi Pada PT. Tambora Mulyorejo Malang Jawa Timur). Jurnal Administrasi Bisnis, volume 26 (2) 1 8.

Ginda. 2002. Koperasi Potensi pengembangan Ekonomi. Pekanbaru: Suska Press

Halim, Abdul. 2010. Dasar-dasar Akuntansi Biaya. Edisi4. Yogyakarta: BPFE

Hall, James A. 2009. Accounting Information System. Jakarta: Salemba Empat.

Irfai, Muhammad. 2009. Sistem Akuntansi Penerimaan Kas Dan Angsuran Pinjaman Pada Koperasi Syirkah Muawanah Bondho Tumoto Kecamatan Gunung Pati Semarang. Skripsi tidak diterbitkan. Universitas Negeri Semarang.

Lestari, Oktavia dkk. 2012. Pembayaran Angsuran Kredit Dalam Mencapai Pengendalian Intern (Studi Pada Bank Perkreditan Rakyat Terusan Jaya Mojokerto). Skripsi tidak diterbitkan. Universitas Brawijaya.

Umar, Husein. 2013. Metode Penelitian untuk Skripsi dan Tesis. Jakarta: Rajawali

Marshall B. Romney,dan Paul John Steinbart. 2015. Sistem Informasi Akuntansi, Edisi 13. Jakarta: Salemba Empat.

Mulyadi. 2010. Sistem Akuntansi, Edisi ke-3. Penerbit Salemba Empat, Jakarta.

Mulyadi. 2011. Auditing Buku 1. Jakarta: Salemba 
Setyosari, Punaji. 2010. Metode Penelitian Pendidikan dan Pengembangan. Jakarta: Kencana.

Setyowati, Atik dkk. 2014. Sistem Akuntansi Pengeluaran Kas Pada Unit Simpan Pinjam KUD Karya Mina Kota Tegal. Tesis tidak diterbitkan. Politeknik Harapan Bersama.

Sirat, Muhidin.2006. Penelitian Tindak Kelas. Jakarta: Gaung Persada

Soemarso. 2009. Akuntansi Suatu Pengantar.Buku ke 2. Edisi 5. Jakarta: Salemba Empat

Sugiyono. 2009. Metode Penelitian Kuantitatif, Kualitatif dan R\&D. Bandung : Alfabeta.

Susanto, Azhar. 2009. Sistem Informasi Akuntansi. Bandung: Lingga Jaya.

Supriyati. 2011. Metodologi Penelitian. Bandung: Labkat press.

Warren, Reeve and Fess. 2005. Accounting: Pengantar Akuntansi. Diterjemahkan: Aria Farahmita, Amanugrahani, dan Taufik Hendrawan. Edisi 21. Buku 2. Salemba Empat. Jakarta.

Pengertian dan pedoman koperasi. Tersedia padahttp://www.sjdih.depkeu.go.id/fullt ext/1992/25TAHUN 1992UU.htm.

Diakses tanggal 15 Februari 2018 pukul 15.08 WITA.

Laporan arus kas. Tersedia pada http://www.iaiglobal.or.id/files/2011/04/ PSAK-2-Laporan-Arus-Kas.pdf. Diakses tanggal 26 Februari 2018 $\begin{array}{lll}\text { pukul } & 09.45 & \text { WITA. }\end{array}$ 